\title{
Microfinance and Public Local Infrastructure Development in Local Councils in Cameroon: The Social Innovation Prospective Approach
}

\author{
Serge Messomo Elle \\ Department of Banking and Finance, University of Buea, Buea, Cameroon
}

Email address:

messomo2011@yahoo.fr

\section{To cite this article:}

Serge Messomo Elle. Microfinance and Public Local Infrastructure Development in Local Councils in Cameroon: The Social Innovation Prospective Approach. International Journal of Business and Economics Research. Special Issue: Microfinance and Local Development. Vol. 9, No. 4, 2020, pp. 241-253. doi: 10.11648/j.ijber.20200904.21

Received: May 4, 2020; Accepted: June 22, 2020; Published: July 22, 2020

\begin{abstract}
Local development is an alternative to central government at the local level. Unlike the case with the central government, local development is directed towards local territories usually with the goal of developing their local resources one of which is local infrastructure. This infrastructure is usually financed by public and private sector capitals. The main objective of this study was therefore to prospect the contributions of microfinance social innovations to public local infrastructure development in local councils in the South, Far North, South West, and North West regions of Cameroon. Government's periodicals and literature on microfinance were used for data collection. The data were analyzed according to contributions, determinants, and challenges of microfinance social innovations in the context of public local infrastructure development in local councils in the regions studied. The findings revealed that the North West and South West regions which retain a higher number of Microfinance Institutions are amenable to more microfinance social innovations which are likely to increase public local infrastructure development in their local councils. This is not the case for the South and Far North regions. Meanwhile, the core challenge faced by municipal authorities in creating public local infrastructure is the lack of mastery and non-respect of both non-financial and financial regulations. We suggest based on the findings above that local councils studied should increase stakeholders' cooperation and participation in public local infrastructure development in their localities, if they hope to boost public local infrastructure development in their municipalities.
\end{abstract}

Keywords: Challenges, Cameroon Microfinance Social Innovations, Public Local Infrastructure Development, Partnerships, Participation, Local Councils, Stakeholders' Cooperation

\section{Introduction}

Over the years, governments have deployed many systems of administration to manage public affairs. These include centralization, deconcentration, and decentralization. Centralization enables the central government to administer local public affairs from the central level. With regard to deconcentration, the central government deploys agents and its services at the local level to manage local affairs. Meanwhile, with decentralization local institutions and governments empowered to handle local public affairs. These affairs could be political, economic, social, cultural and environmental. The management of these affairs takes place within a local territory and this requires local infrastructure for such management to translate to development. However, the development of these infrastructures is not always given the same attention or priority in the different municipalities. Within centralization, it is the central government that is entrusted with the resources to manage the affairs of the council while within decentralized system of administration it is the responsibility of the local governments to ensure the development of the municipalities.

According to [1], Less Developed Countries do not have enough financial resources to finance their local economic development and by extension, their local infrastructure development. This insufficiency of financial resources to spur local economic development is overcome by public private partnerships whereby the central government or local 
institutions together with the private sector pool resources to finance local infrastructure development. [2] acknowledges that the central and local systems of management can also lead to the mobilization of financial resources for the financing of local infrastructure. The success of this cooperation depends on the social proximity between the central government and local government authorities [2].

In Cameroon, decentralization originated from Law no $96 / 06$ of the $18^{\text {th }}$ January 1996 relating to the revision of Cameroon's constitution of $2^{\text {nd }}$ June, 1972. This law introduced decentralization and local authorities in Cameroon. These authorities are local councils and regions. Their executive bodies are, made up of Mayors and their deputies for local councils and the President of Regional Council and his/her Bureau for regions. The legislative bodies are made up of assemblies of councilors and regional councilors respectively. The first transfer of competences to local authorities and specifically local councils took place in 2010. This was followed on $22^{\text {nd }}$ September, 2004 by the publishing of the decentralization directives and also by the statement of laws no 2004/18 and no 2004/019 providing rules applied to councils and regions respectively. Between 2004 and 2019, many other laws were put in place by the government of Cameroon to reinforce decentralization, local economic development and local infrastructural development in Cameroon. The apex of these laws is the decentralization framework law no $2019 / 024$ of $24^{\text {th }}$ December 2019 set up by the Cameroon government to institute the General Code of Regional and Local Authorities in Cameroon. This law avails common provisions applicable to local authorities, the status of local elected officials, the rules governing the organization and functioning of local authorities, the financial regime of local authorities and special regulations applicable to certain local authorities. The implementation of provisions of this General Code of Decentralization in Cameroon requires accompanied measures that involve the private sector and other actors in the development of local authorities and public local infrastructure in Cameroon.

Public local infrastructure is one of the key elements to enable local councils to carry out public local development. Unfortunately, the creation of these infrastructures is affected by many constraints amongst is the financing. Practically, the core sources of financing of public local infrastructure are local Taxes managed by Special Council Support Fund for Mutual Assistance (FEICOM) and subsidies from Cameroon 's central government and agencies like National Community-Driven Development Programme (PNDP).

In 2016, 2017 and 2018 for instance, FEICOM distributed local taxes amounts of 68591786381 FCFA $^{1}, 73995388223$ FCFA and 78613431774 respectively to local councils for their operating and investment activities (Ministry of Decentralization and Local Development, 2019[3] making an annual percent increase in financing of 7.88 in 2017 and 5.22 in 2018. In terms of subsidies, the Government Investment Subsidies Fund (DGI) funded local councils investment

\footnotetext{
${ }^{1} 1$ Euro $=655.957$ FCFA
}

activities in 2018 of 5000000000 FCFA and in 2019 of 36 000000000 FCFA resulting to a percent increase in financing of 620 in 2019 [3]. Despite these sources of finance, Regional and Local Council Authorities (RLAs) in Cameroon are still facing constraints in mobilizing financial resources for their operations specifically for the financing of public local infrastructure. Some of the constraints incurred by these local authorities are insufficient resources resulting from transferred taxes with regard to the new powers of RLAs, low return on taxes transferred to RLAs, huge revenue losses observed in the RLAs resource mobilization channel for various reasons (assignment errors, poor accounting, computer malfunctions), delay in the provision of resources to RLAs due to the irrational functioning of the single treasury account, poor collaboration between state tax services and RLA tax services. These limits in local funds mobilization can be overcome by creating private sources of financing for local councils particularly for the financing of public local infrastructure using the instrument Public Private Partnership (PPP) as suggested by the law no 2006/012 of $29^{\text {th }}$ December, 2006.

According to [4], the PPP has not been enough exploited by Local councils in Cameroon to fund projects like public lighting, mass urban transport by bus or tram, construction and management of conference centers, theatres, festival halls, construction and management of bus stations, construction and management of markets or shopping centers, construction of city or town halls, construction of eco-parks, urban forests, construction and management of public toilets and/or showers. Thus, PPP has many benefits for public local infrastructure development in Cameroon and microfinance can be one of the main private partners in implementing it in local councils for public local infrastructure development.

Microfinance is proximity finance with multiple capacities of social innovations [5] that can assist in the decentralization and public local infrastructure development in Cameroon. Based on the above, we generated the main research question for this study as follows: What microfinance social innovations can contribute to local infrastructure development in Cameroon's local councils and regions?

According to [6], local development has three main dimensions that are economic, social and environmental. The nature of this development can positively influence the nature of public local infrastructure set up in local territories. This can be backed up by factors sustaining microfinance social innovations and can also be constrained by microfinance resources and regulations. Given these factors and limits, we developed the following specific questions for this study:

What microfinance social innovations can contribute to the public local economic, social, cultural and environmental infrastructure development in Cameroon?

What are the determinants of microfinance social innovations that can increase the public local economic, social, cultural and environmental infrastructure development in Cameroon?

What are challenges that can impede public local 
economic, social, cultural and environmental infrastructure development in Cameroon?

The objective of this research is to prospect what microfinance social innovations can contribute to public local economic, social, cultural and environmental infrastructure development in local councils and regions in Cameroon. This research uses a prospective research design and analyses secondary data collected from both the Ministry of Finance, the public projects' financing for the budgetary year 2020 and microfinance literature. The framework of content analysis was adopted. The core finding of this study showed that more local councils have microfinance institutions, more they have microfinance social innovations that can contribute to public local infrastructure development in local councils in regions studied in Cameroon. This is the case of the South West and North West regions of Cameroon. This study is divided in many sections after the introduction which is section one. Section 2 features the analysis of the relationship between local infrastructure development and local development, while section 3 presents an assessment of the link between microfinance social innovations and local public infrastructure development. Section 4 includes an examination of the theoretical framework, and section 5 articulates the methodology of this study, while section 6 presents the findings and accompanying discussions. Finally, the conclusion and policy implications of this study are found in section 7 .

\section{Local Infrastructure Development: A Mechanism to Local Development}

The concept of local development stems from studies of Liaison Entre Actions de Développement de l'Economie Rurale in 1991. It entails the use of a bottom -up approach to support local initiatives and collaborative projects. The notion anchors on the economic, social and environmental development and resilience of rural communities [6]. According to [6], the scope of local development is the region which uses resources contained within. Local development is thus recognized as a process of ameliorating economic, social and environmental conditions of a given area based on the use of local resources in order to improve the well-being and quality of life of the local population [7]. Going by this definition, local development evolves within a territory with specific economic, social and environmental needs. The latter are satisfied by developing local economic, social, cultural and environmental infrastructure in a territory. In this study, local infrastructure is associated with a specific territory that is a region or a local council.

Infrastructure on its part is viewed as networked systems that facilitate the circulation of people, goods, energy, services and information. It has both a collective and a spatial dimension [8]. Thus, the infrastructure first function is social and rooted in collective and networked uses within a particular geographical area. Therefore, local infrastructure development is made up for a local territory development. It encompasses the planning, construction and operation of local infrastructure within a local territory [9]. Infrastructures are classified as economic, social, cultural, environmental or territorial [10]. This classification can also be associated to local infrastructures. [10] conceives economic infrastructures as transport and energy networks. Social infrastructures are health and educational infrastructures while cultural infrastructures are cultural artistic, historic heritage, theatre, music, cinema and entertainment, sport and other aspects. Environmental infrastructures are water purification plant, waste disposal, green areas, and other aspects. According to [10], the territory infrastructures are tourist infrastructures, trade infrastructures and monetary intermediation infrastructures. In this study, we adopt the classification of economic, social, cultural and environmental infrastructures. This is because it suits aligns with the classification of local infrastructures within the public administration structure in Cameroon where this study is carried out.

All infrastructures mentioned above are found in local regions and territories. Their development in planning, construction, operations and maintenance varies according to their nature. Economic infrastructure for instance requires significant capital investments in construction and maintenance. This is explained by the fact that they are extremely so long-lived that it will be expensive to replace them [8]. The development of economic infrastructure is constrained at the local level by the scarcity of local financial resources. The central government, which is in charge to build these infrastructures at local regions for its own benefits, in most Less Developed Countries (LDC) [1], also faces difficulties because of concurrent national commitments. Nevertheless, local economic infrastructures when properly invested generate local economic development to local territories in terms of direct and indirect benefits. The nature of benefits is commercial and noncommercial relationships: cultural, economic, educational and social exchanges; markets and other non market social systems and interdependence within and across local communities. Other benefits provided by local economic infrastructure development are the mitigation of poverty, inequality and local social exclusion, the promotion of local entrepreneurship and the attraction of investment in the local territory, which creates an enabling environment for local economic development and assists in establishing local structures for governance and management of local infrastructure development.

Social infrastructures are infrastructures that produce social value to human beings. In other words, these infrastructures contribute to human being development in a variety of ways including human capital development through educational infrastructures, environmental protection, health care security and assurance through environmental and health infrastructures respectively. Social infrastructures also assist in the protection of cultural heritage. These social infrastructures enable local territories to protect and build a common heritage and identity that differentiates each local territory from the other [4]. Local 
public social and environmental infrastructure development promote local culture, and the green economy, and nurtures social innovations and establishes a strong base for gender focus and sustainable development [11]

Territory infrastructures have both the characteristics of local economic and social infrastructures in local territories. The preceding conceptual review shows that local infrastructure development is a propelling mechanism for local economic, social cultural and environmental development. Therefore, local infrastructures are a tool to be strengthened for a sustainable local development (SLD). One tool that facilitates the attainment of this objective is microfinance social innovations.

\section{Microfinance Social Innovations as a Tool to Public Local Infrastructure Development}

Modern microfinance emerged in 1970s in Bangladesh from the initiatives of Muhammad Yunus and the Grameen Bank. It is an endogenous revolution of financial practice. Its origin is explained by the theory of financial liberalization that revealed two things: first, the collapse of the traditional and the international financial institutions in financing local economic development and small scale economic sectors, and second, the capacity of local communities and institutions to locally generate financial resources to sustain local development and small scale entrepreneurs. These entrepreneurs were excluded from traditional banking services because they could not afford the regular instruments of creditworthiness of commercial banks. Some of these instruments include collaterals, capital, condition, capacity and character. Microfinance through its social innovations overcame these constraints by enabling poor women and youths, and microenterprises to get access to financial services adapted to the nature of their socioeconomic conditions. By attaining this objective, microfinance enables the poor and the excluded to be integrated in the local consumption and production systems. Microfinance achieves the results above by innovating. These innovations can be analyzed from the financial perspective [12] or from the social perspective [13]. From the financial perspective, microfinance financial innovations are perceived at the micro and meso levels. At the micro, they are financial products (microcredits, microsavings, microinsurance, money transfer, training, counseling, and group formation), financial processes (individual lending, group lending, integrated lending, voluntary savings, compulsory savings etc), financial institutions (cooperatives, microprivate banks, mutual funds, investment funds, commercial banks). At the meso level, these innovations are microfinance sectorial regulations and microfinance industry. The two levels of microfinance financial innovations are different from microfinance social innovations.

At the social approach, microfinance social innovations are seen as instruments that promote sustainable development in order to create employment and reinforce competition. Such a development is economic, social, cultural and environmental. In other words, social innovations produce economic, social, cultural and environmental development and lead to other types of innovations [14]. Social innovations are localized within a territory and are designed for the sustainable development of local communities [15]. Microfinance also known as proximity finance or capital for social innovations contributes to the development of local communities through local infrastructures built in local territories.

Microfinance social innovations that can boost local infrastructure development are knowledge-based innovations, participatory approach innovations and organizational innovations [5] Knowledge-based social innovations advocate that microfinance is a field of production of social knowledge and skills useful for proximity financial services, local development and the financing of local infrastructures. Examples are services based on individual or group lending, and services based on age, gender and social proximity. Knowledge-based services enable microfinance to generate collective learning, growth, and participation in the running of affairs of local communities or of a local territory. Microfinance also favors the emergence of new social organizations and organizational governance. Examples are cooperatives, mutual organizations, local agricultural fund and local health fund. New governance mechanisms: a twotier board of directors each having client representatives in managerial bodies' decisions in microfinance institutions.

The social innovations of microfinance can play a great role in public local infrastructure development. Knowledge-based social innovations for instance aid in the planning of local infrastructure development adapted to the needs of beneficiaries and responding to the environmental challenges of the local territory. Participatory social innovations of microfinance permit stakeholders of diversified interests to participate in the development process of local infrastructure and secure themselves their specific interests in the public local infrastructures being created. This is successfully done in communities that have microfinance organizations that retain proximity and social relations in constructing public local infrastructures in local councils and regions. In Cameroon, Law no 2004/018 of $22^{\text {nd }}$ July, 2004 expedited the process of decentralization and transfers of competences and financial resources to local authorities that are local councils and regions. This opens opportunities for these local authorities to enter in partnerships with Non Governmental Organizations (NGOs) and private institutions to strengthen their competences and financial resources' mobilization and local infrastructure development. This is the case with NGOs such as Association Enfant Jeune Avenir (ASSEJA) and Organisation Sociale d'Appui aux Acteurs et aux processus de Développement Local (ASSOAL) that assisted local councils in the development of local infrastructure like water wells, and the construction of rural path roads, toilet buildings and local electricity installation in 2010 [16]. ETRAFOR for instance assisted in developing management committees for roads and bridges in Local Councils in Bafoussam 2 [16]. 


\section{Theoretical Framework}

\subsection{Theoretical Foundation: Social Innovation}

This study uses social innovations' components to examine the contributions of microfinance innovations on the local infrastructure development in local councils and regions in Cameroon. According to [15], social innovations are studied at three dimensions that are: social innovation as a tool of modernization of public policies; social innovation as a developmental instrument of social entrepreneurs and social innovation as a mechanism for inclusion, territoriality and participation.

In the first dimension, social innovation assists governments and local authorities to review and strengthen social policies. It is also used to boost public actions. In this dimension, microfinance uses its social mission to enhance public action [5] by creating social partnerships with the central and local governments for local economic, social, cultural and environmental development [17]. This also applies to public local infrastructure development. The second dimension of social innovation shows that social innovation is a source of emergence for social development and solidarity organizations that facilitate redistribution in local communities. Social enterprises or organizations create profit-making activities to generate financial resources for their non-profit making activities. For [18], these enterprises must be profitable to be socially sustainable. Microfinance creates social enterprises that contribute to economic, social and environmental infrastructure development. The third dimension of social innovation relates to inclusion, territoriality and participation. This is adapted to the social technology of microfinance. The mechanisms of social technology are group participation, village participation, local communities' involvement in local governance affairs, and social, physical and temporal proximity and confidence. All these social innovation instruments are needed to create public local inclusive infrastructure.

[5] showed that microfinance has factors that improve its social performance. These factors determine social innovations. [15] have identified some factors at the origin of social innovations. Some of these are the governance culture of institutions and cooperation between stakeholders of organizations. [5] also identified factors that impede social innovations' development. These could be regulations and resources. These determinants and challenges of social innovations are also identified in microfinance social innovations and also influence public local infrastructure development.

\subsection{Variables Considered in the Study}

The presentation of the theoretical framework of this study provides three sets of variables for this study. They are independent variables, dependent variables and moderated variables.

1. Independent variables

i. Independent variable: Microfinance social innovations:
Modernization of public policies, participatory mechanisms for inclusion and development of social entrepreneurs

The independent variable is microfinance social innovations. These microfinance social innovations are identified from the perspective of microfinance social mission which is to satisfy social stakeholders such as customers and the local communities. The social innovations are embodied in the social mission of microfinance and this study has identified three independent variables considered as social innovations of microfinance. They are modernization of public policies, participatory mechanisms and development of social entrepreneurs

ii. Independent variable: Determinants of social innovations: Organizational culture and stakeholders' cooperation.

The second set of variable is factors boosting social innovations in microfinance. These are organizational culture and stakeholders' cooperation [13].

iii. Independent variable: Challenges to microfinance social innovations: They are regulations and resources. They are seen in this study as hindrances and constraints to social innovations [15].

\section{Dependent variable}

This is the variable that is affected by independent variables. This variable in this research is public local infrastructure development. It is captured by subvariables namely needs in planning, construction, operation and location of public local economic, social, cultural and environmental infrastructures

\section{Moderated variables}

They comprise indicators that reinforce the influence of independent variables on dependent variables. They are of two types. They are MFIs and the legal status of MFIs. These variables are designed to strengthen the action of microfinance social innovations on public local infrastructure development.

\subsection{Propositions of the Study}

Based on the variables above and the theoretical foundations of social innovations, we developed the propositions below for this study:

$\mathrm{P}_{1}$ : Local councils and regions with diversified MFIs, have microfinance social innovations that can overcome the needs of development of public local economic, social, cultural and environmental infrastructure in their locations.

$\mathrm{P}_{2}$ : Local councils and regions with diversified MFIs can generate determinants of microfinance social innovations decreasing the needs of development of public local economic, social, cultural and environmental infrastructure in their areas.

$\mathrm{P}_{3}$ : Local councils and regions with diversified MFIs can have fewer challenges to microfinance social innovations hindering development of public local economic, social, cultural and environmental infrastructure in their localities. 


\subsection{Theoretical Design}

\section{Independent Variables}

\section{Moderated variable}

Microfinance

Social Innovation (MIS)
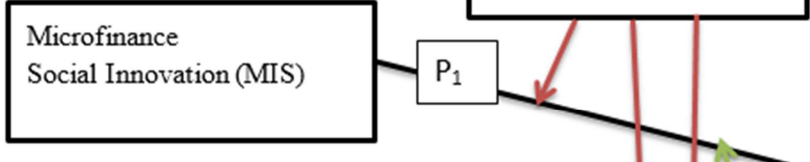

Dependent variable

-Modernization of Public policies

-Participatory Mechanisms for Inclusion

-Development of Social Entrepreneurs

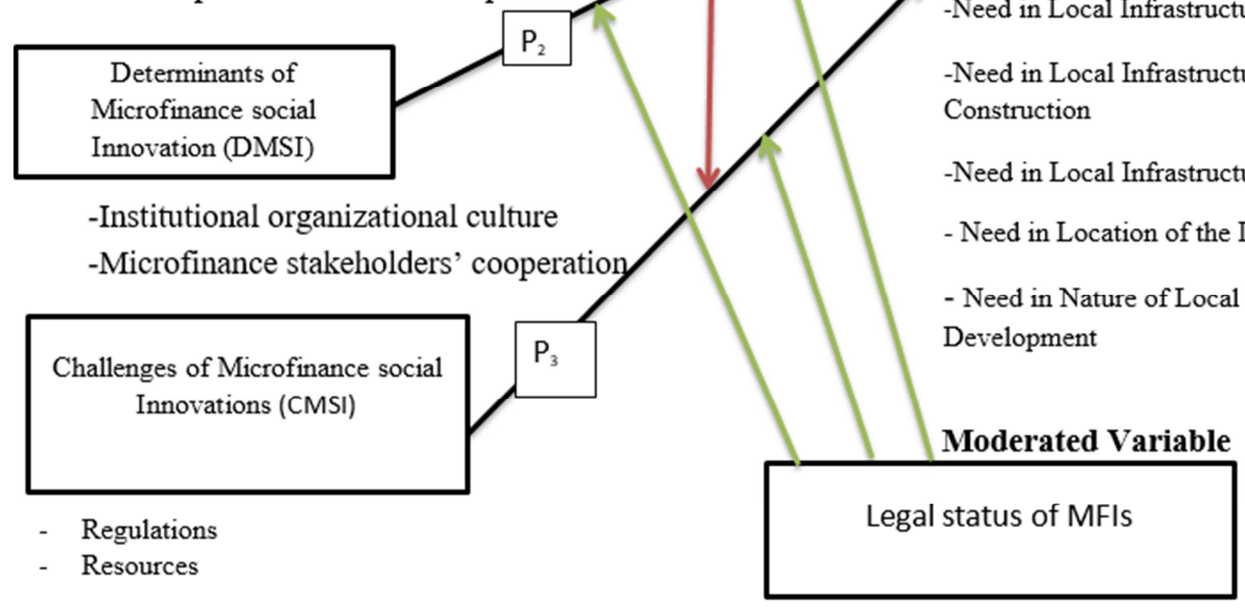

Public Local Infrastructure Development

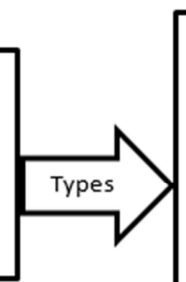

- Public Local

Economic Infrastructure

Development

Public Local Social

Infrastructure

Development

-Public Local Cultural

Infrastructural

Development

- Public Local

Environmental

infrastructural

Development

Figure 1. Theoretical Design of Microfinance Social Innovation and Public Local Infrastructural Development.

\section{Methodology}

This section under study presents the operationalization of variables, the sources of data collection and instruments of data analyses. The operationalization of variables provides measures of adopted variables. These are given on Table 1.

\subsection{Operationalization of Variables}

The operationalization of variables in this study is done as a process: variables, subvariables and measures.

Table 1. Operationalization of Variables.

\begin{tabular}{|c|c|c|c|}
\hline Variables & Subvariables & Measures & $\begin{array}{l}\text { Referent } \\
\text { Authors }\end{array}$ \\
\hline \multicolumn{4}{|l|}{ Independent variables } \\
\hline \multirow{3}{*}{$\begin{array}{l}\text { Microfinance Social } \\
\text { Innovations (MSI) }\end{array}$} & Modernization of public policies & $\begin{array}{l}\text { Productive knowledge in public policies, collective/organizational } \\
\text { learning, and integration of resources in public policies }\end{array}$ & \multirow{3}{*}{$\begin{array}{l}{[5,19]} \\
{[9]}\end{array}$} \\
\hline & $\begin{array}{l}\text { Participatory mechanisms for } \\
\text { inclusion }\end{array}$ & $\begin{array}{l}\text { Partnerships between stakeholders, diversity of institutions and } \\
\text { stakeholders, proximity, and trust }\end{array}$ & \\
\hline & Development of social entrepreneurs & $\begin{array}{l}\text { Cooperative institutions, joint liability group institutions, mutual funds } \\
\text { institutions, participatory customers' organisations, and corporation } \\
\text { microbanks, financial products/services for social entrepreneurs }\end{array}$ & \\
\hline \multirow[b]{2}{*}{$\begin{array}{l}\text { Determinants of } \\
\text { Microfinance Social } \\
\text { Innovations (DMSI) }\end{array}$} & Organizational culture & Market-based, innovative, Ethnic and administrative & \multirow[b]{2}{*}[15]{} \\
\hline & Stakeholders' cooperation & $\begin{array}{l}\text { Stakeholders' participation in institutional governance, stakeholders' } \\
\text { empowerment, collective interests' satisfaction, territorial and local } \\
\text { interests and rules' development }\end{array}$ & \\
\hline \multirow{2}{*}{$\begin{array}{l}\text { Challenges of Microfinance } \\
\text { Social Innovations (CMSI) }\end{array}$} & Regulations & Financial, non financial & \multirow{2}{*}[15]{} \\
\hline & Resources & Financial, human and social & \\
\hline \multicolumn{4}{|l|}{ Moderated Variables } \\
\hline $\begin{array}{l}\text { Microfinance Institutions } \\
\text { (MFIs) }\end{array}$ & l & Number of MFIs & \multirow[t]{3}{*}[20]{} \\
\hline Legal Status & & Corporation MFIs, Cooperative MFIs and NGOs & \\
\hline Dependent variables & & & \\
\hline
\end{tabular}




\begin{tabular}{lll}
\hline Variables & Subvariables & Measures \\
\hline & Need in Planning & Seferent \\
& Need in construction & Construction specification, completed structure acceptance \\
\hline Local Infrastructure & Need in operation & Operation conditions, maintenance, and retirement \\
Development (LID) & Need in location & Local councils, and regions \\
& Need in nature of local infrastructure & Economic, social, cultural and environmental \\
\hline
\end{tabular}

\subsection{Sources and Instruments of Data Collection}

The data used in this study is secondary. It was collected from the Cameroon Government's daily newspaper Cameroon Tribune and also from the literature on microfinance and social innovations. Data were also collected from four regions of Cameroon that are South, Far-North, North-West and South West. These regions were chosen based on their convenience and availability of data.

The data for the moderated variable were collected from the list of Microfinance Institutions in 2017 published in [22] no $11632 / 7831$ by the Ministry of Finance of Cameroon. Some of the measures of the dependent variables like the nature of the local infrastructure and their locations were collected from the book projects of the Cameroon Government for the budgetary year 2020 published in [23] no $12016 / 8215$ of $20^{\text {th }}$ January, 2020. The independent variables were collected from the studies of [15] on social innovation and its multiple usages and also from the studies of [5] on Microfinance as a capital for innovation. The process of analyzing these data is given below.

\subsection{Method and Instruments of Data Analyses}

The data were analyzed according to the three propositions defined in 4.3. The first proposition is analyzed by determining the microfinance social innovations suitable to satisfy the needs of the local councils and regions, studied in terms of the nature of public local infrastructure studied, number and types of MFIs that are Affiliated, Independent cooperatives, private Microbank Corporations and NGOs/Projects. The regions studied for data convenience are south, Far-North, North-West and South-West.

The second proposition provides the nature of determinants of microfinance social innovations that meet the needs of constructed public local infrastructure development in these regions. The decrease in needs is measured by the number of cooperative MFIs found in each region compared to Corporation MFIs. The third proposition is analyzed by describing the nature of the problems based on the ratios, number of MFIs-Number of public local infrastructure per region and Number of MFIs-Number of local councils per region. Thus, the lower the ratios per region, the greater the challenge and problems for microfinance social innovations to sustain public local infrastructure development in local councils and regions studied, and vice-versa.

\section{Presentation and Discussion of Results}

\subsection{Results}

\subsubsection{Proposition One}

Table 2 shows the type and number of local infrastructures to be constructed by local councils in the south, Far North, South West and North West regions from Cameroon's 2020 budget. Table 2 also shows the types of MFIs located in local councils and regions and the local infrastructures constructed for the budgetary year 2020. From Table 2, it then appears the North West Region has more MFIs than the local infrastructure budgeted for construction in this region at a percentage of 186.95 This is not the case with the South Region which has more local infrastructures and less MFIs with a percentage of 9.86 of the ratio number of MFIs number of infrastructures. The South West region is the second region following this ratio with 82.1 percent while the Far North has 12.7 percent.

Table 2. Types of Local Infrastructure and MFIs in Local Councils and Regions Studied.

\begin{tabular}{|c|c|c|c|c|c|c|c|c|c|c|c|}
\hline \multirow{2}{*}{ Region } & \multicolumn{5}{|c|}{ Types of Infrastructure } & \multicolumn{5}{|c|}{ Types of MFIs } & \multirow{2}{*}{$\begin{array}{l}\text { Ratio MFIs to Number of Infrastructure } \\
\text { Percent }\end{array}$} \\
\hline & $\mathbf{E C}$ & SO & $\mathbf{C U}$ & EN & Total & $\mathbf{A F}$ & IC & MBC & NGO/PRO & Total & \\
\hline South & 32 & 33 & 3 & 3 & 71 & 4 & 3 & 0 & 0 & 7 & 9.86 \\
\hline Far North & 20 & 75 & 0 & 15 & 110 & 10 & 3 & 0 & 1 & 14 & 12.7 \\
\hline South West & 22 & 36 & 0 & 9 & 67 & 49 & 4 & 2 & 0 & 55 & 82.1 \\
\hline North West & 4 & 41 & 0 & 1 & 46 & 74 & 9 & 3 & 0 & 86 & 186.95 \\
\hline Total & & & & & 294 & & & & & 162 & 55.1 \\
\hline
\end{tabular}

Source: From Analyses of Data in [22; 23]

EC= ECONOMIC INFRASTRUCTURE; SO = SOCIAL INFRASTRUCTURE; CUI= CULTURAL INFRASTRUCTURE; EN = ENVIRONMENTAL INFRASTRUCTURE AF= AFFILIATED; IC = INDEPENDENT COOPERATIVES;

$\mathrm{MBC}=$ MICROBANK CORPORATION; NGO= NON GOVERNMENTAL ORGANIZATIONS; PRO=PROJECTS

The higher percentages of the ratio of MFIs to the number of infrastructures in the North West and South West regions are supported by the setting up of many Affiliated (AF) and
Independent Cooperatives (IC) in these regions. These MFIs can be suitable for many social innovations like productive knowledge and collective learning necessary at the planning 
and construction of public local infrastructure [20]. Figure 2 the regions studied. provides the distribution of local infrastructure and MFIs in

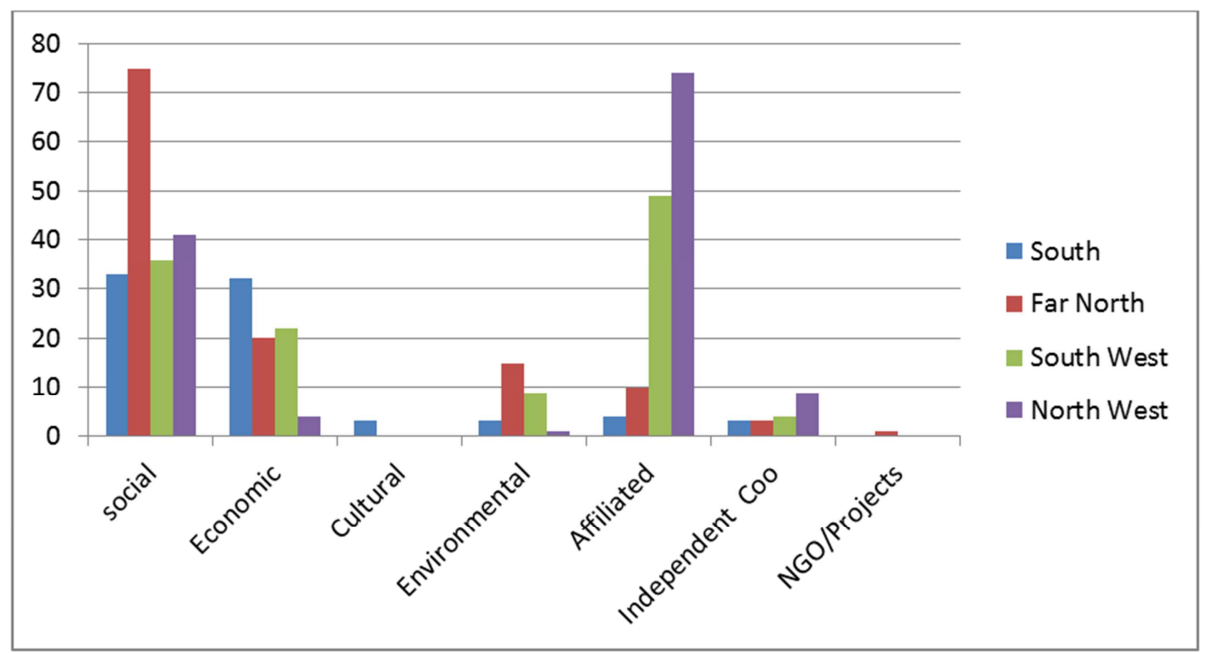

Source: From Analyses of Data in [22; 23]

Figure 2. Distribution of public local infrastructure and MFIs in the regions studied.

Figure 2 shows that local councils in the Far North Region will construct more social and environmental public local infrastructures from Cameroon's 2020 budget than in the other regions studied while the local councils of the South region are first in economic and cultural public local infrastructures. This could be explained by the fact that the Far North Region is affected by the war against Boko Haram, which amongst others causes poverty amongst inhabitants in that region. Environmentally, the region is classified as an area threatened by ecological destruction and desert because of its level of drought. This is not the case with the South Region which offers many economic and cultural opportunities thanks to its wild life and large zones of forest. The North West and South West regions dominate in the number of MFIs because they are the birthplace of microfinance in Cameroon. The possible contributions to Local Infrastructure Development are examined on Table 3.

Table 3. Contributions of Microfinance Social Innovations to Local Infrastructure Development.

\begin{tabular}{|c|c|c|c|c|c|}
\hline Region & $\begin{array}{l}\text { Number of } \\
\text { Councils }\end{array}$ & $\begin{array}{l}\text { Number of } \\
\text { Councils } \\
\text { with MFIs }\end{array}$ & $\begin{array}{l}\text { Ratio Number } \\
\text { of MFIs to } \\
\text { Councils } \\
\end{array}$ & $\begin{array}{l}\text { Needs in Infrastructure } \\
\text { Development (ID) }\end{array}$ & $\begin{array}{l}\text { Possible Contributions of } \\
\text { MSOI }\end{array}$ \\
\hline South & 65 & 5 & $\begin{array}{l}10.8 \\
\text { Percent }\end{array}$ & $\begin{array}{l}\text { Need of } \mathrm{MBC}, \mathrm{NGO} / \text { Projects MFIs to } \\
\text { support the operation and maintenance } \\
\text { of } \mathrm{EC}, \mathrm{SO}, \mathrm{CU} \text { and } \mathrm{EN}\end{array}$ & $\begin{array}{l}\text { Participations of beneficiaries and civil societies } \\
\text { and Business persons of MBC and NGOs in ID; } \\
\text { Productive and Collective Knowledge to create } \\
\text { MBC and NGO MFIs in Local Councils }\end{array}$ \\
\hline Far North & 125 & 7 & $\begin{array}{l}11.2 \\
\text { Percent }\end{array}$ & $\begin{array}{l}\text { Planning and construction of CU } \\
\text { Infrastructure; Need of MBC MFIs to } \\
\text { support the operation and maintenance } \\
\text { of EC, SO, CU and EN }\end{array}$ & $\begin{array}{l}\text { Productive and organizational Knowledge in } \\
\text { developing cultural infrastructure, Participations of } \\
\text { MBC MFIs stakeholders in ID in local Councils; } \\
\text { Creation of MBC MFIs }\end{array}$ \\
\hline $\begin{array}{l}\text { South } \\
\text { West }\end{array}$ & 73 & 13 & $\begin{array}{l}75.3 \\
\text { Percent }\end{array}$ & $\begin{array}{l}\text { Planning and construction of CU } \\
\text { Infrastructure; } \\
\text { Lack of NGO/PRO MFIs to support the } \\
\text { operation and maintenance of EC, SO, } \\
\text { CU and EN Infrastructure }\end{array}$ & $\begin{array}{l}\text { Productive and organizational Knowledge in } \\
\text { developing cultural infrastructure, Participations of } \\
\text { Civil Societies and NGOs/PRO MFIs stakeholders } \\
\text { in ID in local Councils; Creation of NGOs/PRO } \\
\text { MFIs }\end{array}$ \\
\hline TOTAL & 311 & & 52.1 & & \\
\hline
\end{tabular}

Source: From Analyses of Data from $[22 ; 23 ; 5 ; 19 ; 15]$

ID = Infrastructure Development; MSOI = Microfinance Social Innovations

Table 3 provides the needs in local infrastructure development in local councils and regions studied. From Table 3, results show that Local councils in the Far North, South West and North West regions did not plan for the construction of public local cultural infrastructures in the 2020 budget. This reveals the need for local councils in these regions to develop cultural Knowledge, participatory, organizational and product innovations in these regions with 
the assistance of MFIs located in these areas to construct and operate public local cultural infrastructure. The specificities of social innovations of Affiliated MFIs operating in these regions can be integration of local resources, financing of social entrepreneurs and empowerment of other stakeholders to assist to build sustainable public local infrastructure in local councils of Far North, South West and North West regions.

Meanwhile, one or two types of MFIs are not found in each of the regions studied. In the South region for instance, we have Microbank Corporation (MBC), NGOs and Project (PRO), while in Far North region, Microbanks are lacking, and in South West and North West regions, NGOs and Projects are not created. Table 4 details the determinants of Microfinance Social Innovations that can increase infrastructure development.

\subsubsection{Proposition Two}

Table 4 presents the determinants of microfinance social innovations that can decrease the needs in local infrastructure development in local councils and regions studied. These determinants are NGOs, Microbank and civil society values and Stakeholders cooperation in local infrastructure development for local councils in the South Region. In the Far North region, they are cultural local infrastructure and private corporation MFIs' values and stakeholders' cooperation in sustainable local infrastructure development. In the North West and South West regions, they are cultural local infrastructure, NGO and projects' values and needs of collaboration to develop strong public local infrastructure in the local councils of these regions. Determinants of the moderated variable MFIs can assist in public local infrastructure development in these ways: NGOs will enable to finance public local infrastructure at a low cost while Corporation MFIs will permit to optimize the resources in the planning, construction, operation and maintenance of public local infrastructures. Affiliated MFIs will encourage the training and mobilization of local resources to decrease the needs in public local infrastructure development in regions studied mostly in the Far North, South West and North West regions affected by wars.

Table 4. Determinants of Microfinance Social Innovations that can boost Local Infrastructure Development.

\begin{tabular}{|c|c|c|}
\hline Region & $\begin{array}{l}\text { Needs in Infrastructure } \\
\text { Development (ID) }\end{array}$ & Determinants of Microfinance Social Innovations \\
\hline South & $\begin{array}{l}\text { Needs of } \mathrm{MBC}, \mathrm{NGO} / \text { Projects MFIs to support } \\
\text { the operation and maintenance of } \mathrm{EC}, \mathrm{SO}, \mathrm{CU} \\
\text { and } \mathrm{EN}\end{array}$ & $\begin{array}{l}\text { Introduction of } \mathrm{NGO} / \mathrm{PRO} \text { and Private corporation MBC values in Local councils and in } \\
\text { their executives; Cooperation between local council authorities and stakeholders of EC, } \\
\mathrm{SO}, \mathrm{CU}, \mathrm{EN}, \mathrm{AF}, \mathrm{IC} \text { and opening to new stakeholders in the local ID process like NGOs } \\
\text { and promoters of MBC }\end{array}$ \\
\hline Far North & $\begin{array}{l}\text { Planning and construction of CU Infrastructure; } \\
\text { Needs of MBC MFIs to support the operation } \\
\text { and maintenance of EC, SO, CU and EN }\end{array}$ & $\begin{array}{l}\text { Cultural and private corporation MFI Values of Local councils and their executives; } \\
\text { Cooperation between local council authorities and stakeholders of EC, SO, EN, AF, IC, } \\
\text { NGOs and collaborations with new stakeholders like promoters of MBC MFIs to plan and } \\
\text { construct cultural infrastructure }\end{array}$ \\
\hline South West & $\begin{array}{l}\text { Planning and construction of CU Infrastructure; } \\
\text { Lack of NGO/PRO MFIs to support the } \\
\text { operation and maintenance of EC, SO, CU and } \\
\text { EN }\end{array}$ & $\begin{array}{l}\text { Cultural and NGO MFI Values and Mission at Local councils; Cooperation between local } \\
\text { council authorities and stakeholders of EC, SO, EN, AF, IC and collaborations with new } \\
\text { stakeholders like promoters of NGOs and PRO MFIs to plan and construct cultural } \\
\text { infrastructure }\end{array}$ \\
\hline North West & $\begin{array}{l}\text { Planning and construction of CU Infrastructure; } \\
\text { Lack of NGOs/PRO to support the operation } \\
\text { and maintenance of EC, SO, CU and EN }\end{array}$ & $\begin{array}{l}\text { Cultural and NGO/PRO Values and Mission at Local councils; Cooperation between local } \\
\text { council authorities and stakeholders of EC, SO, EN, AF, IC and collaborations with new } \\
\text { stakeholders like promoters of Civil societies development and PRO MFIs to plan and } \\
\text { construct cultural infrastructure }\end{array}$ \\
\hline
\end{tabular}

Source: From Analyses of Data from $[22 ; 23 ; 5 ; 19 ; 15]$

\subsubsection{Proposition Three}

Table 5. Challenges of Microfinance Social Innovations to Local Infrastructure Development.

\begin{tabular}{llll}
\hline Region & $\begin{array}{l}\text { Ratio MFI-Number of } \\
\text { Infrastructure (in percent) }\end{array}$ & $\begin{array}{l}\text { Ratio MFIs- number of } \\
\text { Local Councils (in percent) }\end{array}$ & Challenges to Microfinance Social Innovations \\
\hline South & 9.86 & 10.8 & Financial and Non financial resources; Financial non financial regulations \\
Far North & 12.7 & 11.2 & Financial and Non financial resources; Financial non financial regulations \\
South West & 82.1 & 75.3 & Non financial resources and non financial regulations \\
North West & 186.95 & 179.17 & Non financial resources and non financial regulations \\
\hline
\end{tabular}

Source: From Analyses of Data from $[22 ; 23 ; 5 ; 19 ; 15]$

Table 5 presents the challenges of Microfinance social innovations to local infrastructure development. These challenges are identified as financial and non financial resources and regulations. These challenges were measured from the ratios of number of MFIs to the number of infrastructure and number of MFIs to the number of local councils. Based on the ratios, it is evident that local councils in South West and North West regions have many MFIs suitable that can furnish them with the needed financial resources to foster local infrastructure development. This can enable the local councils of these regions to finance the operation and maintenance of public local infrastructure as well as to generate benefits from these infrastructures for their populations. This is not the case with local councils in 
the South and Far North regions with less MFIs and as a result, the councils are obliged to rely more on central government and local council resources.

All local councils of all the regions studied operate within the decentralization laws and the General code of Regional and Local Authorities of 2019 in Cameroon. Hence, their planning of local infrastructure development is constrained by these regulations. Non financial regulations are perceived in this study as regulations that are not associated with the financial sector or authorities. Figure 3 compares local councils, infrastructures and MFIs.

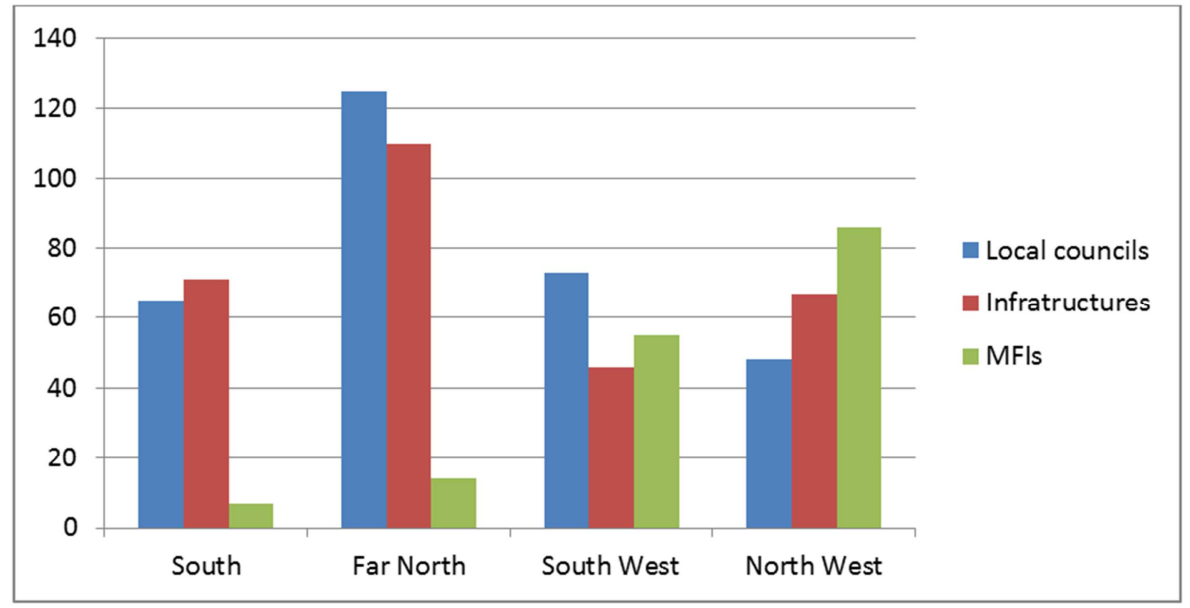

Source: From Analyses of Data in $[22 ; 23]$

Figure 3. Comparison of local councils, local infrastructures and MFIs in local regions studied.

As presented on the bar chart above, the South and Far North regions have more local councils and infrastructure than MFIs. This can hamper their ability to diversify the source of financing for their local infrastructure to include the private sector like MFIs. In addition, this also shows that these regions may have problems to plan for sustainable public local infrastructure development from the regional local resources. They have to rely mostly on either central government funds or on public funds to build up local infrastructure. This is not the case with the North West and South West regions.

\subsection{Discussion of Findings}

The results have revealed that Cameroon's central government transfers financial resources to local councils. These councils use these funds to construct more public local economic and social infrastructures than public local cultural and environmental infrastructures. This can be justified by the fact that local councils following the different laws of decentralization set up in Cameroon since 2010 are requested to be an independent administration and authorities different from the central administration, and each having their own local institutions. To be fully independent and efficient in the activities carried out, local councils need to generate themselves financial and non financial resources to support their development. There is a need for this development to be sustainable. The local councils can do it by having partnership and participation of the private sector through social innovations like microfinance social innovations. This study has revealed that this can be possible in the South and North West regions which have more MFIs. These MFIs are rooted in social values and practices, offer many opportunities of financing and can support local infrastructure development in the North and South West regions than in the South and Far North regions.

The fact that the North West and South West regions also have more MFIs than the other two regions implies that the former can be amenable to more microfinance social innovations for local infrastructure development than the other two regions. The North West and South West regions also can have fewer challenges in financial resources than others as far as financially supporting local infrastructure development is concerned. On the contrary the local regions of the two regions (The North West and South West Regions) do not invest more in local cultural infrastructure. This can be justified by a socio-political crisis that has been rocking these regions from 2016 through 2020, the result of which is that priorities have been given to social and economic infrastructures destroyed in these regions. The said social infrastructures can also assist in the effective management of the Covid-19 pandemic at local council levels. This can be achieved by applying participatory and cooperation mechanisms that are at the foundation of social innovations.

The results presented above are in line with the studies of [5] which showed that microfinance is a rich source of capital and social innovations and these are the engine of development, in the case of this study, local infrastructure development. [6]) and [4] showed that this development is successful when it is rooted in local territories and local resources. The findings of this study are similar to the above findings given that the North and South West regions, present a very high number of affiliated and independent cooperative MFIs that are rooted in local communities and these can 
contribute to the construction of public local infrastructure in the local councils of these regions.

\section{Conclusion and Policy Implications}

Microfinance social innovations are an incentive to public local infrastructure development and the findings of this research have supported this. Its main objective was to determine the microfinance social innovations that can contribute to public local infrastructure development in selected local councils and regions of Cameroon. The study used a descriptive research design and data collected were secondary. The data were analyzed using percentages and content information collected, were analyzed thematically. The main finding is that microfinance social innovations are likely to contribute more to public local infrastructure development in the North West and South West regions than in the South and Far North regions. This is because these regions host many Affiliated and Independent Cooperatives and these can easily be involved in local infrastructure development. This study adds to theory because it shows that public organizations can use the private organizations' social innovations to improve their social welfare and social performance goals through their participation in local development and specifically in local infrastructure development.

In terms of policy implications, the study suggests that local councils can strengthen their social innovations of knowledge creation, participation, stakeholders' cooperation and public private partnerships to develop public local infrastructure. This study has some limitations in terms of scope and this can be overcome by studying all the ten regions of Cameroon, using a time series analysis. The inferential analysis could also be incorporated to ameliorate the scientific quality of the findings.

\section{Appendix}

Table 6. Local Councils and Number of projects studied.

\begin{tabular}{lll}
\hline Region & Local Councils & $\begin{array}{l}\text { Number of Projects } \\
\text { Carried out per Council }\end{array}$ \\
\hline Far North & \\
& Maroua III council & 2 \\
Pette Council & 2 \\
Bogo Council & 1 \\
Meri Council & 2 \\
Ndoukoula Council & 3 \\
Gazawa Council & 2 \\
Dargala Council & 1 \\
Maroua II council & 2 \\
Maroua I council & 2 \\
Tokomberie Council & 1 \\
Kaele Council & 9 \\
Moutourwa Council & 1 \\
Mindif Council & 2 \\
Dziguilo Council & 5 \\
Touloum Council & 3 \\
Porhi Council & 1 \\
Moulvoudaye Council & 11 \\
Guidiquis council & 1 \\
Kousseri Council & 5 \\
\hline
\end{tabular}

\begin{tabular}{|c|c|c|}
\hline Region & Local Councils & $\begin{array}{l}\text { Number of Projects } \\
\text { Carried out per Council }\end{array}$ \\
\hline & Waza Council & 4 \\
\hline & Darak Council & 4 \\
\hline & Fotokol Council & 2 \\
\hline & Makary Council & 2 \\
\hline & Logone-Bimi Council & 1 \\
\hline & Goulfey Council & 1 \\
\hline & Hale-Alifa Council & 1 \\
\hline & Zina Council & 1 \\
\hline & Blangoua Council & 1 \\
\hline & Mora Council & 8 \\
\hline & Tokomberi Council & 4 \\
\hline & Kolofata Council & 4 \\
\hline & Mokolo Council & 1 \\
\hline & Mogode Council & 2 \\
\hline & Bourrha Council & 1 \\
\hline & Yagoua Council & 1 \\
\hline & Kalfou council & 2 \\
\hline & Kai-Kai Council & 11 \\
\hline & Wina Council & 3 \\
\hline & Guere Council & 2 \\
\hline & Tchatibali Council & 6 \\
\hline & Maga Council & 2 \\
\hline & Gueme Council & 3 \\
\hline & Vele Council & 1 \\
\hline & Kar-Hay Council & 1 \\
\hline & Datcheka Council & 1 \\
\hline \multirow{11}{*}{$\begin{array}{l}\text { Total } \\
\text { South West }\end{array}$} & & 126 \\
\hline & & \\
\hline & Tiko Council & 4 \\
\hline & Limbe II Council & 5 \\
\hline & Limbe III council & 3 \\
\hline & Buea Council & 3 \\
\hline & Muyuka Council & 1 \\
\hline & Limbe I council & 2 \\
\hline & Mamfe Council & 4 \\
\hline & Upper Bayang Council & 5 \\
\hline & Eyou modjock Council & 1 \\
\hline \multirow[t]{20}{*}{1} & Tinto Council & 1 \\
\hline & Idenau Council & 2 \\
\hline & Akwaya Council & 1 \\
\hline & Ekondo-Titi Council & 2 \\
\hline & Isangelle Council & 3 \\
\hline & Idabato Council & 1 \\
\hline & Kombo-Etindi Council & 1 \\
\hline & Bamousso Council & 1 \\
\hline & Kumba I council & 5 \\
\hline & Mbonge Council & 3 \\
\hline & Mbonge Council & 3 \\
\hline & Kumba II Council & 2 \\
\hline & Kumba III council & 2 \\
\hline & Konye Council & 1 \\
\hline & Wabane Council & 4 \\
\hline & Menji Council & 2 \\
\hline & Alou Council & 1 \\
\hline & Bamgem Council & 4 \\
\hline & Tombel Council & 4 \\
\hline & Nguti Council & 2 \\
\hline \multirow{9}{*}{$\begin{array}{l}\text { Total } \\
\text { North West }\end{array}$} & & 73 \\
\hline & & \\
\hline & Tubah Council & 2 \\
\hline & Santa Council & 2 \\
\hline & Bamenda Council II & 5 \\
\hline & Bafut Council & 1 \\
\hline & Bamenda Council & 1 \\
\hline & Bamenda III Council & 1 \\
\hline & Bali Council & 1 \\
\hline
\end{tabular}




\begin{tabular}{lll}
\hline Region & Local Councils & Number of Projects \\
Carried out per Council
\end{tabular}

Table 7. Microfinance Institutions Studied.

\begin{tabular}{lll}
\hline REGION & $\begin{array}{l}\text { AFFILIATED } \\
\text { CORPORATIVES }\end{array}$ & LOCALITY OF MFIs \\
\hline \multirow{2}{*}{ SOUTH } & 4 & -KRIBI \\
& & -SANGMELIMA \\
& & -MENGONG \\
FAR NORTH & 10 & -MAROUA (4) \\
& & -MAYO SAWA (2) \\
& & -DAMARE \\
\hline
\end{tabular}

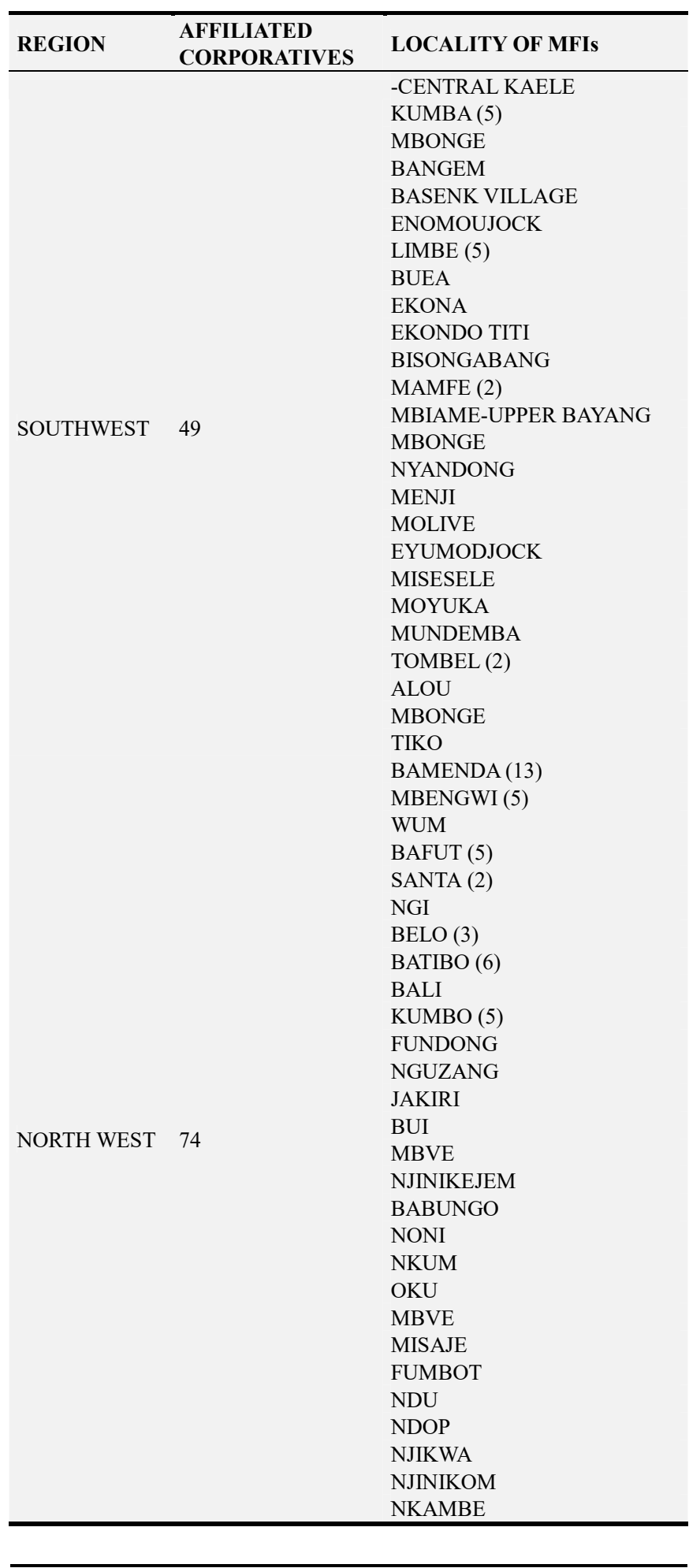

\section{References}

[1] Eudes Jean-Baptiste (2018). Les mécanismes de financement du développement économique local: caractérisations et stratégies adaptées aux PMA. Gestion et Management. Université Paris-Saclay.

[2] Fabre, B. (2018). «Les facteurs politiques des finances publiques locales: un Etat des lieux». Vie \& Sciences de l'entreprise. Vol. 2, no 206, 20-36. 
[3] Ministry of Decentralization and Local Development (2019). Proceedings Of The General Conference Of Local Councils.

[4] Decentralization.com (2019). Local DevelopmentInauguration Of Infrastructural Projects In Councils, Yaounde, SOPECAM.

[5] Antohi, M. (2009). "Microfinance, Capital for Innovation" in Social Innovation and Territorial Development, ASHGATE ebook Publishing Limited.

[6] Milan-Garcia, J., Uribe-Toril, J., Ruiz-Real, J. R. \& J. D. P., Valenciano (2019). "Sustainable Local Development: An Overview of the State of Knowledge", Resources, 8, 31, 1-8.

[7] Dawkins, C. J. (2003). "Regional Development Theory: Conceptual Foundations, Classic works, and recent Development". Journal of Planning Literature, 18, 131-172.

[8] Frischmann, B. M. (2012). Infrastructure -The Social Value of Shared Resources- Oxford/New-York: Oxford University Press.

[9] Moulaert, F. (2009). "Social Innovation: Institutionally Embedded, Territorially (Re) Produced" in Social Innovation and Territorial Development, ASHGATE e-book Publishing Limited.

[10] ISTAT (2006). "Le Infrastructture in Italia. Un'analisi della dotazione e della funzionlita". Rome.

[11] Amin, A. (1999). "An Institutionalist Perspective on Regional Economic Development". International Journal of Urban Regional Resources, 23, 365-378.

[12] Messomo, E. S. (2018). "Financial and Institutional Innovations in Microfinance Innovations and Commercial Banks in Cameroon". International Journal of Financial Innovation in Banking, Vol. 2, no 2, pp. 143-157.

[13] Blach, J. (2011). "Financial Innovations and Their Role in the Modern Financial System-Identification and Systematization of the Problem", eFinanse.

[14] Bouchard, M. (2006). «De l'expérimentation à l'institutionnalisation positive: l'innovation sociale dans le logement communautaire au Québec». Public and Cooperative Economics, 77 (2), 139-166.

[15] Richez-Battesti, N., Petrella, F. \& Vallade, D. (2012). «L'innovation sociale: Une notion aux usages pluriels: Quels enjeux et défis pour l'analyse?» Innovations, Vol. 2, no 38, $15-36$

[16] COPADECOM (2010). Expériences des collaborations entre les organisations de la société civile et les communes dans un contexte de décentralisation. Coopération Allemande \& CVUC.

[17] Messomo, E. S. (2013d). «Réglementation et inclusion financière en microfinance au Cameroun». La microfinance contemporaine-Défis et perspectives. Première Edition, France, Presses Universitaires de Rouen et Havre, décembre.

[18] Yunus, M. (2007). Vers un nouveau capitalisme, Paris, le livre de Poche.

[19] Messomo. E. S. (2015). "Revisiting the Theory of Social Capital Through the Financing of Microentrepreneurs in Cameroon using Fuzzy Decision Tree and QFD". Int. J. Entrepreneurship and Small Business, Vol. 26, no 3, pp. 352367.

[20] Messomo, E. S. (2012). "Rethinking Microentrepreneurs' Financing by Microfinance Institutions in Cameroon: Human or Economic Capital?" American Journal of Entrepreneurship, Vol. 5, Issue 2, pp. 88-108.

[21] Torrisi, G. (2009). Public Infrastructure: Definition, Classification and Measurement issues. RePEc.

[22] Cameroon Tribune (2018). "Microfinance Institutions authorized to carry out Microfinance Activities in Cameroon", no $11632 / 7831$, July 6 .

[23] Cameroon Tribune (2020). "Operations Book per Region, Division, Head, Programme and Action, Financial Year 2020", no 12016/8215, January, 20. 